\title{
ДИНАМІКА ПОКАЗНИКІВ ЕНДОГЕННОӦ ІНТОКСИКАЦІЇ ЗА УМОВ ЕКСПЕРИМЕНТАЛЬНОГО СИНДРОМУ ТРИВАЛОГО СТИСНЕННЯ
}

\author{
๑Я. І. Юрик, Я. Я. Боднар, А. С. Сверстюк, І. І. Юрик \\ Тернопільський національний медичний університет імені І. Я. Горбачевського МОз України
}

\begin{abstract}
РЕзюмЕ. Розвиток генералізованої токсемії $\epsilon$ однією з ключових ланок патогенезу синдрому тривалого стиснення.

Мета - вивчити динаміку змін показників ендогенної інтоксикації у крові та серці білих лабораторних щурів за умов експериментального синдрому тривалого стиснення.

Матеріал і методи. Дослідження проведено на 68 білих лабораторних щурах вагою 240-270 грам, яких поділили на такі групи: 1 - інтактні тварини (14 особин); 2 - 1-ша доба спостереження (14 особин); 3 - 3-тя доба спостереження (12 особин); 4 - 7-ма доба спостереження (16 особин) та 5 - 14-та доба спостереження (12 особин). Евтаназію щурів здійснювали кровопусканням в умовах тіопенталового наркозу через 1, 3, 7 та 14 діб дослідження. Токсичність крові оцінювали за еритроцитарним індексом інтоксикації та за вмістом молекул середньої маси. У гомогенаті тканини серця та крові визначали концентрації малонового діальдегіду. Кількісні показники обробляли статистично.

Результати. При проведенні досліджень установлено, що за умов експериментального СТС зростають показники ендогенної інтоксикації. Вміст МСМ зростав через 24 години спостереження і набував максимальних значень через три доби, з наступним зменшенням через 7 та 14 діб. Еритроцитарний індекс інтоксикації зростав 3 першої доби дослідження у 2,7 раза й утримувався на такому ж рівні через три доби з наступним зменшенням через 7 та 14 діб. При зіставленні динаміки змін вмісту малонового діальдегіду в крові та тканині серця встановлено, що максимальних значень вони набувають у ранньому посткомпресійному періоді з переважанням у тканині серця через 24 години, а через три доби і до закінчення експерименту цей показник був вищим у сироватці крові.

Висновки. У посткомпресійному періоді СТС розвивається ендотоксикоз, що підтверджує значне зростання вмісту MCM та Ell у період між першою та третьою добами експерименту з максимумом на третю добу, що відповідає ранньому посткомпресійному періоді. Компресійна травма м'язів за умов СТС призводить до активації пероксидного окиснення ліпідів, маркером якого є зростання рівня МДА в сироватці крові та тканині серця.

КлючОВІ СлОВА: ендогенна інтоксикація, щури, синдром тривалого стиснення.
\end{abstract}

Вступ. Суть синдрому тривалого стиснення (СТC) полягає в тривалому стисканні кінцівок, аж до припинення кровопостачання їх тканин і розвитку ішемії. Патогенез СТС зумовлений відновленням кровопостачання тканин, які піддавалися стисненню впродовж певного терміну (3 год і більше) і характеризується розвитком больового шоку, генералізованої ендотоксемії, втрати рідкої частини крові, дисемінованого внутрішньосудинного згортання крові, гострої ниркової та поліорганної недостатності. Головними ланками розвитку синдрому тривалого стиснення вважають ішемію та венозний застій у посмугованих м'язах, реперфузійну токсемію внаслідок всмоктування кровоносним руслом продуктів розпаду білків, гіперкаліємію та міоглобулінемію, метаболічний ацидоз, синдром дисемінованого внутрішньосудинного згортання, больовий синдром [1, 2]. Клінічно та експериментально розвиток у посткомпресійному періоді СТС таких тяжких ускладнень як респіраторний дистрес-синдром, гостра гіповолемія, гіповолемічний шок, постішемічний набряк тканин, генералізований ендотоксикоз та реперфузійна токсемія або реперфузійний цитоліз $є$ головними чинниками, які призводять до ураження всіх органів і систем, розвитку поліорганної недостатності та є причиної смерті потерпілих [3]. Одним із найчутливіших показників розвитку ендогенної інтоксикації $€$ визначення молекул середньої маси (МСМ), що дає змогу оцінити стадію та тяжкість стану потерпілих $[4,5]$.

Мета роботи - вивчити динаміку змін показників ендогенної інтоксикації у крові та серці білих лабораторних щурів за умов експериментального синдрому тривалого стиснення.

Матеріал і методи. Дослідження проведено на 68 білих лабораторних щурах вагою 240270 грам. Піддослідні тварини були поділені на такі групи: 1 - інтактні тварини (14 особин); 2 1-ша доба спостереження (14 особин); 3 - 3-тя доба спостереження (12 особин); 4 - 7-ма доба спостереження (16 особин) та 5 - 14-та доба спостереження (12 особин). Терміни виведення експериментальних тварин з експерименту відповідали періодам розвитку синдрому тривалого стиснення: від 1 до 3 діб - ранній період; від 3 до 7 діб - проміжний період; від 7 до 21 доби - пізній (відновний період) [6].

СТС моделювали шляхом стискання м'яких тканин стегна правої тазової кінцівки за умов зне- 
Огляди літератури, оригінальні дослідження, погляд на проблему, випадок з практики, короткі повідомлення

болення шляхом внутрішньоочеревинного введення кетаміну гідрохлориду (100 мг/кг маси тіла), сила компресії становила 7 кг/см² на $5 \mathrm{~cm}^{2}$ протягом 6 годин без ушкодження магістральних судин та кісток [7]. Виведення піддослідних тварин з експерименту здійснювали шляхом кровопускання після внутрішньоочеревинного введення тіопенталу натрію у дозі 50 мг/кг через 1, 3, 7 та 14 діб дослідження. Токсичність крові оцінювали за еритроцитарним індексом інтоксикації (EII) [8] та за вмістом молекул середньої маси (МСM), зокрема MCM $_{254}$ та MCM $_{280}[9,10]$. У гомогенатах тканини серця та крові визначали концентрацію малонового діальдегіду (МДА) [11].

Утримання щурів і експеримент виконані відповідно до вимог "Європейської конвенції про захист хребетних тварин, що використовуються для експериментів та інших наукових цілей" (Страсбург, 1986). При роботі з тваринами дотримувались правил поводження з експериментальними тваринами згідно з директивою Ради ЄC 2010/63/EU про дотримання постанов, законів, адміністративних положень Держав ЄС з питань захисту тварин, які використовуються з науковою метою $[12,13]$.

Отриманий у результаті експерименту цифровий матеріал систематизований та оброблений за допомогою методів варіаційної статистики з використанням програми «Microsoft Exel 6,0».

Результати й обговорення. Одним із важливих факторів розвитку ендотоксемії та маркером ендогенної інтоксикації $є$ зростання в сироватці крові потерпілих МСМ, якими є сполуки молекулярною масою 300-5000 дальтон. До складу МСМ входять похідні глюкуронової кислоти, продукти розпаду фібриногену, тромбіну, альбуміну, пептиди, речовини деградації колагену, гормони інсулін та глюкагон та інші складники [14]. Маючи високу біологічну активність за умов ендотоксемії вони посилюють мембранну проникність, гемоліз еритроцитів, перешкоджають засвоєнню глюкози, знижують синтез ДНК та глобіну в еритробластах, інгібують фагоцитарну активність лейкоцитів, пригнічують всі види обміну і завдяки цитотоксичній та імунодепресивній дії поглиблюють тяжкість стану потерпілих.

Для вибору статистичного методу оцінювання достовірної відмінності спочатку було проведено перевірку на нормальність усіх досліджуваних показників: ElI, MCM $_{254}$ MCM $_{280}$ та МДА в програмі «Statistica 10.0». Аналізуючи отримані результати, а також кількість спостережень в експериментальних групах тварин (від $n=12$ до $n=16$ ), ми зробили висновок про відмінність від нормального закону розподілу досліджуваних показників. Оскільки усі досліджувані показники (EII, $\mathrm{MCM}_{254}$ MCM $_{280}$ та МДА) не відповідають нормаль- ному закону розподілу, а одночасно для кожного показника буде проводитися 5 порівнянь (контрольна група, через 1, 3, 7, 14 діб після проведеного експерименту), зроблено висновок про доцільність застосування непараметричного критерію Краскела - Уолліса.

3'ясовано, що за умов експериментального СТС показники МСМ значно зростають. Через 24 години після експерименту вміст MCM $_{254}$ у сироватці крові зріс на 114,3 \%, а показник МСM $_{280}$ - на $157,1 \%$, або, відповідно, у 2,1 та 2,5 раза, порівняно з інтактною групою ( $<<0,001)$. Через 3 доби дослідження вміст MCM $_{254}$ зріс ще на $28 \%$, або у 2,4 раза, а показник MCM $_{280}$ збільшився на 42,9 \% порівняно з 1-ою добою спостереження, та у 3 рази від аналогічного показника тварин інтактної групи $(p<0,001)$. Через 7 діб після моделювання СТС вміст MCM $_{254}$ та MCM $_{280}$ знизився, порівняно з попередніми термінами експерименту, але статистично вірогідно ( $p<0,001)$ перевищував показники інтактних тварин відповідно на 57,1 \% та 92,3 \%. Тенденцію до зниження вмісту МСМ ми спостерігали і через 14 діб дослідження, коли показники MCM $_{254}$ та $\mathrm{MCM}_{280}$ стали найменшими, порівняно з іншими групами дослідження, але перевищували відповідні дані у інтактних щурів на 28,6 \%, що не було статистично достовірно ( $p>0,05)$, та 42,9 \% відповідно ( $p<0,001)$. Треба зауважити, що найвищим вміст MCM $_{254}$ був через 1 та 3 доби після моделювання СТС і він утримувався на приблизно на однаковому рівні, який перевищував відповідний показник у інтактних тварин у 2,1 раза. Враховуючи склад MCM $_{254}$ до яких входять пептиди, тригліцериди, продукти розпаду нуклеїнових кислот, речовини деградації колагену, таке підвищення рівня MCM $_{254}$ сприяє руйнуванню структурних компонентів клітинних мембран. Вміст MCM $_{280}$ також зріс через 24 години після проведення експерименту в 2,5 раза, а через три доби був більшим від аналогічного показника тварин інтактної групи у 3 рази. Такі дані можуть свідчити про зрив адаптаційнокомпенсаторних та детоксикаційних процесів у піддослідних тварин.

Важливим критерієм ендогенної інтоксикації за умов експериментального СТС вважається EII, рівень якого зростав одночасно з підвищенням вмісту в крові МСМ (табл. 1). Найістотніше збільшення цього показника ми відмічали через одну та три доби після моделювання СТС. Так, через 24 години він достовірно перевищував рівень інтактних тварин на $173,8 \%$ ( $<<0,001)$, а через три доби - на 176,3 \% ( $p<0,001)$, або у 2,7 раза. Через 7 діб експерименту Ell залишався вищим на 136,1 \% ( $p<0,001)$. Через 14 діб показник Ell знизився, проте він залишався статистично вірогідно вищим, ніж у інтактних щурів, на 80,6 \% ( $p<0,001)$. 
Огляди літератури, оригінальні дослідження, погляд на проблему, випадок з практики, короткі повідомлення

Таблиця 1. Динаміка змін показників МСM та Ell в ранній, проміжний та пізній періоди розвитку синдрому тривалого стиснення

\begin{tabular}{|l|c|c|c|c|c|}
\hline \multirow{2}{*}{ Показник } & \multicolumn{5}{|c|}{ Групи тварин } \\
\cline { 2 - 6 } & інтактні & 1 доба & 3 доба & 7 доба & 14 доба \\
\hline MCM $_{254, \text { ум. од. }}$ & $0,07 \pm 0,005$ & $0,15 \pm 0,01$ & $0,017 \pm 0,01$ & $0,11 \pm 0,01$ & $0,09 \pm 0,01$ \\
$(p<0,05)$ & $(p<0,01)$ & $0,001)$ \\
\hline MCM $_{280, \text { ум. од }}$ & $0,14 \pm 0,01$ & $0,36 \pm 0,01$ & $0,042 \pm 0,01$ & $0,27 \pm 0,01$ & $0,20 \pm 0,00$ \\
& & $(p<0,001)$ & $(p<0,001)$ & $(p<0,001)$ & $(p<0,001)$ \\
\hline EII \% & $32,73 \pm 0,99$ & $89,60 \pm 0,62$ & $90,44 \pm 0,24$ & $77,29 \pm 0,45$ & $59,12 \pm 0,70$ \\
& & $(p<0,001)$ & $(p<0,001)$ & $(p<0,001)$ & $(p<0,001)$ \\
\hline
\end{tabular}

Безперечно, можна припустити, що компресійний стрес зумовлює активацію пероксидного окиснення ліпідів. Одним із маркерів ствердження зазначеної гіпотези є визначення концентрації МДА в сироватці крові та гомогенаті серця. Нами з'ясовано, що рівень вмісту МДА в сироватці крові через 24 години після усунення компресії зростав, порівняно з групою інтактних тварин, у 3 рази $(p<0,001)$, а в тканині серця - у 3,6 раза $(p<0,001)$, через три доби вміст МДА у крові підвищився в 4 рази, а в гомогенаті серця - у 3,7 раза, що було найвищим у посткомпресійному періоді. Згодом рівень МДА повільно зменшувався, але залишався статистично достовірно вищим у крові через 7 діб у 3,3 раза ( $<<0,001)$ і через 14 діб у 2,6 раза ( $p<0,001)$, у тканині серця, відповідно, - у $2,4(p<0,001)$ та 2,1 раза ( $p<0,001)$, що було статистично достовірно, порівняно з тваринами інтактної групи. Слід зауважити, що через 24 години експерименту вміст МДА переважав у тканині серця на 65,1\%, але через три доби рівень МДА вже був вищим у сироватці крові на 24,1\%, і така закономірність зберігалася до кінця експерименту (табл. 2).

Таблиця 2. Динаміка змін продуктів пероксидного окиснення ліпідів у сироватці крові та гомогенаті серця в ранньому, проміжному та пізньому періодах розвитку синдрому тривалого стиснення

\begin{tabular}{|c|c|c|c|c|c|}
\hline \multirow{2}{*}{ Показник } & \multicolumn{5}{|c|}{ Групи тварин } \\
\hline & інтактні & 1 доба & 3 доба & 7 доба & 14 доба \\
\hline \multicolumn{6}{|c|}{ Сироватка крові } \\
\hline МДА, мкмоль/л & $1,91 \pm 0,03$ & $\begin{array}{l}5,74 \pm 0,08 \\
(p<0,001)\end{array}$ & $\begin{array}{l}7,60 \pm 0,06 \\
(p<0,001)\end{array}$ & $\begin{array}{l}6,38 \pm 0,10 \\
(p<0,001)\end{array}$ & $\begin{array}{l}5,06 \pm 0,06 \\
(p<0,001)\end{array}$ \\
\hline \multicolumn{6}{|c|}{ Гомогенат серця } \\
\hline МДА, мкмоль/кг & $0,99 \pm 0,06$ & $\begin{array}{l}3,62 \pm 0,05 \\
(p<0,001)\end{array}$ & $\begin{array}{l}3,70 \pm 0,04 \\
(p<0,001)\end{array}$ & $\begin{array}{l}2,39 \pm 0,09 \\
(p<0,001)\end{array}$ & $\begin{array}{l}2,11 \pm 0,09 \\
(p<0,001)\end{array}$ \\
\hline
\end{tabular}

Висновки. У посткомпресійному періоді СТС розвивається ендотоксикоз, що підтверджують значне зростання вмісту МСМ та ЕІІ у період між першою та третьою добами експерименту з максимумом на третю добу, що відповідає ранньому посткомпресійному періоду. Компресійний стрес за умов СТС призводить до активації пероксидного окиснення ліпідів, маркером якого $є$ зростання рівня МДА в сироватці крові та тканині серця.
Перспективи подальших досліджень. Подальші дослідження будуть спрямовані на поглиблене вивчення процесів пероксидного окиснення ліпідів, активності антиоксидантних ферментів у посткомпресійному періоді експериментального синдрому тривалого стиснення.

\section{ЛІТЕРАТУРА}

1. Индивидуальный прогноз острого повреждения почек у больных с сочетанной травмой / И. А. Мизиев, М. Х. Махов, А. К. Жигунов [и др.] // Медицина катастроф. - 2014. - № 4 (88). - С. 18-20.

2. Zimmerman J. L. Rhabdomyolysis / J. L. Zimmerman, M. C. Shen // Chest. - 2013. - Vol. 144, No. 3. - P. 1058-1065.
3. Manson J. Trauma alarmins as activators of damageinduced inflammation / J. Manson, C. Thiemermann, K. Brohi // Br. J. Surg. - 2012. - Vol. 99, No. 1. - P. 12-20.

4. Лабораторная диагностика синдрома эндогенной интоксикации : метод. реком. / под ред. И. П. Корюкиной. - Пермь, 2012. - 35 с. 
Огляди літератури, оригінальні дослідження, погляд на проблему, випадок з практики, короткі повідомлення

5. Чайковская И. В. Синдром эндогенной интоксикации и его роль при патологических процессах / И. В. Чайковская, Л. В. Яворская // Питання експериментальної та клінічної медицини : збірник статей. - Донецьк, 2012. - Т. 16. Вип. 1. - С. 144-151.

6. Нечаев Э. А. Синдром длительного сдавления : руководство для врачей / Э. А. Нечаев, А. К. Ревской, Г. Г. Савицкий. - М. : Медицина, 1993. - 208 с.

7. Далгатова А. А. Иммунопатогенез синдрома длительного сдавления / А. А. Далгатова, М. 3. Саидов // Проблемы экологической медицины : материалы VI Peспубликанской наук.-практ. конф., 20 октября 2016 г. Махачкала, 2016. - С. 238-248.

8. Способ диагностики эндогенной интоксикации / А. А. Тогайбаев, А. В. Кургузкин, И. В. Рикун [и др.] // Лабораторное дело. - 1988. - № 9. - С. 22-24.

9. Скриниговый метод определения средних молекул в биологических жидкостях : методические рекомендации / Н. И. Габриэлян, Э. Р. Левицкий, А. А. Дмитриев [и др.]. - М., 1985. - 36 с.

\section{REFERENCES}

1. Miziev, I.A., Makhov, M.Kh., Zhigunov, A.K., Khatshukov, A.Kh., Dabagov, O.Yu., Akhkubekov, R.A., \& Kardanov, A.V. (2014). Individualnyj prognoz ostrogo povrezhdeniya pochek u bol'nyh s sochetannoj travmoj [Personal prognosis of acute kidney injury in patients with concomitant trauma]. Medicina katastrof-Disaster Medicine, 88 (4), 18-20. [in Russian].

2. Zimmerman, J.L., \& Shen, M.C. (2013). Rhabdomyolysis. Chest, 144(3), 1058-1065.

3. Manson, J., Thiemermann, C., \& Brohi, K. (2012). Trauma alarmins as activators of damage-induced inflammation. The British Journal of Surgery, 99 (1), 12-20.

4. Koryukina, I.P. (2012). Laboratornaya diagnostika sindroma endogennoj intoksikacii (Metodychni rekomendatsii) [Laboratory diagnosis of endogenous intoxication syndrome ((Methodical recommendations)]. Perm [in Russian].

5. Chaykovskaya, I.V., \& Yavorskaya, L.V. (2012). Sindrom endogennoy intoksikatsii i yego rol pri patologicheskikh protsessakh [Endogenous Intoxication Syndrome and its role in pathological processes]. Pytannya eksperymentalnoi ta klinichnoi meditsyny-Questions Experimental and Clinical Medicine : collection of articles. Donetsk [in Ukrainian].

6. Nechaev, E.A., Revskoy, A.K., \& Savitsky, G.G. (1993). Sindrom dlitelnogo sdavleniya (rukovodstvo dlya vrachey) [Prolonged pressure syndrome (guide for doctors)]. Moscow: Medycyna [in Russian].

7. Dalgatova, A.A., \& Saidov, M.Z. (2016). Immunopatogenez sindroma dlitel'nogo sdavleniya [Immunopathogenesis of long-term compression syndrome]. Problemy ekologicheskoy meditsiny - Environmental medicine problems: materialy VI Respublikanskoy nauk.-prakt. konf., 238248. [in Russian].
10. Средние молекулы - образование и способы определения / В. В. Николайчик, В.В.Кирковский, В. М. Маин [и др.] // Лабораторное дело. - 1989. - № 8. C. 31-33.

11. Владимиров Ю. А. Перекисное окисление липидов в биологических мембранах / Ю. А. Владимиров, А. И. Арчаков. - М. : Медицина, 1972. - 252 с.

12. Directive 2010/63/EU of the European Parliament and of the Council of 22 September 2010 on the protection of animals used for scientific purposes [Electronic resource] // Official Journal of the European Union. - 2010. L276. - P. 33-79. URL: https://eur-lex.europa.eu/legal-content/EN/TXT/?uri=celex\%3A32010L0063

13. Guide for the care and use of laboratory animals. 8th ed. - Washington : The National Academies Press, 2011. $-246 \mathrm{p}$.

14. Шано В. П. Синдром эндогенной интоксикации / В. П. Шано, Е А. Кучер // Острые и неотложные состояния в практике врача. - 2011. - № 1. С. 3-8.

8. Togaybaev, A.A., Kurguzkin, A.V., \& Rikun, I.V. (1988). Sposob diagnostiki endogennoo intoksikacii [Method for the diagnosis of endogenous intoxication]. Laboratornoe delo-Laboratory Work, 9, 22-24. [in Russian].

9. Gabrielyan, N.I., Levitsky, E.R., \& Dmitriev, A.A. (1985). Skrinigovyj metod opredeleniya srednih molekul v biologicheskih zhidkostyah (Metodychni rekomendatsii) [Screening method for the determination of medium molecules in biological fluids ( methodological recommendations). Moscow [in Russian].

10. Nikolaychik, V.V., Kirkovskiy, V.V., \& Main, V.M. (1989). Sredniye molekuly - obrazovaniye i sposoby opredeleniya [Medium molecules - formation and methods of determination]. Laboratornoe delo - Laboratory Work, 8, 31-33. [in Russian].

11. Vladimirov, Yu.A., \& Archakov, A.I. (1972). Perekisnoe okislenie lipidov $v$ biologicheskih membranah [Lipid peroxidation in biological membranes]. Moscow : Medycyna [in Russian].

12. Directive 2010/63/EU of the European Parliament and of the Council of 22 September 2010 on the protection of animals used for scientific purposes [Electronic resource] (2010). Official Journal of the European Union, L276, 33-79. URL: https://eur-lex.europa.eu/legal-content/ $\mathrm{EN} / \mathrm{TXT} /$ ?uri=celex\%3A32010L0063

13. Guide for the care and use of laboratory animals (2011). 8th ed. Washington: The National Academies Press.

14. Shano, V.P., \& Kucher, E.A. (2011). Sindrom endogennoj intoksikacii [Endogenous intoxication syndrome]. Ostrye i neotlozhnye sostoyaniya v praktike vracha- Acute and emergency conditions in a doctor's practice, 1, 3-8. [in Ukrainian]. 
Огляди літератури, оригінальні дослідження, погляд на проблему, випадок з практики, короткі повідомлення

\title{
ДИНАМИКА ПОКАЗАТЕЛЕЙ ЭНДОГЕННОЙ ИНТОКСИКАЦИИ В УСЛОВИЯХ ЭКСПЕРИМЕНТАЛЬНОГО СИНДРОМА ДЛИТЕЛЬНОГО СДАВЛЕНИЯ
}

\author{
๑я. И. Юрик, Я. Я. Боднар, А. С. Сверстюк, И. И. Юрик
}

Тернопольский национальный медицинский университет имени И. Я. Горбачевского МОз Украины

РЕЗЮМЕ. Развитие генерализованной токсемии является одним из ключевых звеньев развития патогенеза синдрома длительного сдавления.

Цель - изучить динамику изменений показателей эндогенной интоксикации в крови и сердце белых лабораторных крыс в условиях экспериментального синдрома длительного сдавления (СДС).

Материал и методы. Исследование проведено на 68 белых лабораторных крысах весом 240-270 грамм, которых поделили на следующие группы: 1 - интактные животные (14 особей); 2 - 1-е сутки наблюдения (14 особей); 3 -3-и сутки наблюдения (12 особей); 4 - 7-е сутки наблюдения (16 особей) и 5 - 14-е сутки наблюдения (12 особей). Эвтаназию крыс осуществляли кровопусканием в условиях тиопенталового наркоза через 1, 3, 7 и 14 суток исследования. Токсичность крови оценивали по эритроцитарному индексу интоксикации (ЭИИ) и по содержанию молекул средней массы (МСМ). В гомогенате ткани сердца и крови определяли концентрации малонового диальдегида (МДА). Количественные показатели обрабатывали статистически.

Результаты. При проведении исследований установлено, что в условиях экспериментального СДС растут показатели эндогенной интоксикации. Содержание МСМ возрастало через 24 часа наблюдения и приобретало максимальные значения через трое суток с последующим уменьшением через 7 и 14 суток. ЭИИ возрастал с первого дня исследования в 2,7 раза и удерживался на таком же уровне через трое суток с последующим уменьшением через 7 и 14 суток. При сопоставлении динамики изменений содержания МДА в крови и ткани сердца установлено, что максимальные значения они приобретают в раннем посткомпрессионном периоде с преобладанием в ткани сердца через 24 часа, а через трое суток и до окончания эксперимента этот показатель был выше в сыворотке крови.

Выводы. В посткомпрессионном периоде СДС развивается эндотоксикоз, подтверждающийся значительным ростом содержания МСМ и ЭИИ в период между первыми и третьими сутками эксперимента с максимумом на третьи сутки, что соответствует раннему посткомпрессионному периоду. Компрессионная травма мышц в условиях СДС приводит к активации перекисного окисления липидов, маркером которого является повышение уровня МДА в сыворотке крови и ткани сердца.

КЛЮЧЕВЫЕ СЛОВА: эндогенная интоксикация; крысы; синдром длительного сдавления.

\section{DYNAMICS OF INDICES OF ENDOGENOUS INTOXICATION UNDER EXPERIMENTAL CRUSH-SYNDROME}

\author{
OYa. I. Yuryk, Ya. Ya. Bodnar, A. S. Sverstyuk, I. I. Yuryk \\ I. Horbachevsky Ternopil National Medical University
}

SUMMARY. The development of generalized toxemia is one of the key links in the development of the pathogenesis of crush-syndrome.

The aim - to study the dynamics of changes in the indicators of endogenous intoxication in the blood and heart of white laboratory rats under the conditions of crush-syndrome.

Material and Methods. The research was performed on 68 white laboratory rats weighing 240-270 grams, which were divided into the following groups: 1 - intact animals (14 individuals); 2 - 1st day of observation (14 individuals); 3 - 3rd day of observation (12 individuals); 4th - 7th day of observation (16 individuals) and 5 - 14th day of observation (12 individuals). Euthanasia of rats was performed by bloodletting under conditions of thiopental anesthesia after 1, 3, 7 and 14 days of the research. Blood toxicity was assessed by erythrocyte intoxication index and the content of middle-mass molecules. Concentrations of malonic dialdehyde were determined in the homogenate of heart and blood tissue. Quantitative indicators were processed statistically.

Results. During the research it was established that under the conditions of experimental crush syndrome the indicators of endogenous intoxication increase. The content of MSM increased after 24 hours of observation and reached maximum values after three days, followed by a decrease after 7 and 14 days. The erythrocyte intoxication index increased 2.7 times from the first day of the study and remained at the same level after three days, followed by a decrease after 7 and 14 days. When comparing the dynamics of changes in malonic aldehyde in blood and heart tissue, it was found that they acquire maximum values in the early postcompression period with a predominance in heart tissue after 24 hours, and three days before the end of the experiment this figure was higher in blood serum.

Conclusions. In the postcompression period of crush syndrome develops endotoxicosis, which confirms a significant increase in the content of MSM and Ell in the period between the first and third days of the experiment with a maximum on the third day, which corresponds to the early postcompression period. Compression injury of muscles under the conditions of crush syndrome leads to activation of peroxide oxidation of lipids which marker is increase in level of MDA in blood serum, tissue and heart.

KEY WORDS: crush-syndrome; endogenous intoxication; rats. 